\title{
Mother and Son, Paired
}

One of the curiosities of history that suggests the magnitude of hidden early traditions about Mary is that, according to Averil Cameron, until the era of Iconoclasm images of Jesus with his mother "greatly outnumber" images of Jesus by himself. ${ }^{1}$ Given the modern pious imagination of Mary, one might assume that all these images of mother and son together depicted him as an infant sitting on her lap. That assumption would be wrong. The pairing of Mary and her infant son was important, but their pairing when he was a young man was apparently just as important or even more so.

As demonstrated in the last chapter, some artists vertically paired Mary with her son in scenes where she was depicted lifting her hands and leading the prayer, praising God, and blessing people, while Jesus was depicted in the heavens above her. This core vertical iconography is best explained as art of the Six Books scene where Mary raised her arms and prayed to her son. Other artists, however, paired mother and grown son horizontally. This horizontal pairing, likewise often depicting Mary arms-raised, is found on silver chalices, censers, processional crosses, gold bishops' medallions (the encolpion), gospel book covers, church decoration, and reliquary boxes, as illustrated in this chapter. Most of this precious art is dated between the year 500 and the end of the seventh century and advent of Islam. Toward the end of this chapter, however, I will demonstrate that in some cases, this dating may be too conservative. Some objects may be older.

(C) The Author(s) 2019

A. Kateusz, Mary and Early Christian Women, https://doi.org/10.1007/978-3-030-11111-3_5 
The pairing of mother and son in early Christian art is consistent with the way some narratives paralleled the importance of mother and son. For example, according to the gospels of Matthew and Luke, Jesus was conceived without a man's seed-and, according to the Protevangelium, Mary also was conceived without a man's seed, thusly conceived while her mother's husband was in the wilderness for 40 days. The Protevangelium said an angel first went to Mary's barren mother Anna and announced that she would conceive and next went to her husband, Joachim, who had been in the wilderness forty days, and announced that Anna had conceived. ${ }^{2}$ In the late fourth century, Bishop Epiphanius of Salamis treated this scene as gospel, as it is written. He did not question that Anna had conceived Mary without a man's seed, but he bitterly complained that some people were using this "to make her God, or to have us make offerings in her name, or, again, to make women priestesses." 3 Perhaps, as Epiphanius complained, the belief that Mary was conceived without a man's seed indeed was used to justify offerings in her name and women priests. If so, that might explain why later scribes redacted the scene to add that Mary had a human father. In one popular example, the angel instead announces to Joachim: "Know that she has conceived a daughter from thy seed." 4 Another scribe bluntly added: "Anna conceived from the seed of Joachim." 5 Yet another explained that Mary "was born of a father and a mother even as all men." 6

In another narrative parallel, the canonical gospels depict Jesus as dead, then resurrected, and the oldest surviving Dormition text depicts Mary as dead-and then her son resurrects her. ${ }^{7}$ Likewise, Luke 24:50 depicts Jesus bodily ascending after his resurrection-and the early Dormition text depicts Mary bodily ascending after her resurrection (in her son's chariot). ${ }^{8}$ Accordingly, some Greek Dormition manuscripts use the same word for Mary's ascension-analeppsis-that Luke 9.51 uses for the ascension of Jesus. 9 Their two ascension scenes are paralleled on two side-by-side wood panels on the Santa Sabina Church doors in Rome dated 420-430. ${ }^{10}$ The parallel of their auspicious deaths persisted longer than the parallel of their births - no bones of either Jesus or Mary became relics in the medieval era, because Christians believed that both had been bodily taken up to heaven.

Their sacrificial roles also appear to have been seen as parallel from an early date. Jesus was seen as a sacrifice, and Lily Vuong has detailed how the Protevangelium described Mary as a Temple sacrifice. ${ }^{11}$ Writers called both mother and son the altar, the incense, the lamb, the ark; he was king, she was queen; he was prophet, she prophetess. ${ }^{12}$ The early 
fourth-century poet Ephrem the Syrian called them brother and sister, as well as mother and son. ${ }^{13}$ With these early literary parallels in mind, we examine the way that artists paralleled them on objects used in the liturgy.

\section{Mother And Son Paired on Objects Used in the Liturgy}

Early Byzantine silver objects, many of which were used during the Eucharistic liturgy, provide excellent examples of the liturgical pairing of mother and son. It was rare that Jesus was portrayed on one of these sacred utensils without his mother. ${ }^{14}$ Mother and son, or scenes from their respective lives, were typically placed on opposite faces. In some cases, each stands alone on opposite faces. Sometimes Mary is flanked by angels, or sometimes by male saints, although she may be flanked by a woman and a man on a silver flask that most likely held oil for anointing.

Some of the most exquisite examples of this mother and son pairing are on chalices found in buried hoards of church silver in the Eastern Mediterranean, primarily in and around Ancient Syria. A few chalices, such as three in the Beth Misona Treasure in the Cleveland Museum of Art, have facial portraits of Jesus and Mary on the opposite sides of each chalice. ${ }^{15}$ Most chalices portray their entire body. On these, Mary is almost always depicted with her arms raised. ${ }^{16}$ Likewise, Jesus is almost uniformly depicted as a beardless youth ${ }^{17}$ - a characteristic of the earliest Christian art, such as in the Christian catacombs of Rome. ${ }^{18}$

A treasure of church silver found in Attarouthi in northern Syria paired Mary and Jesus as counterparts on the opposite faces of eight of the ten chalices found. Neither was depicted on the remaining two chalices. ${ }^{19}$ None of these items had silver stamps, but are broadly dated 500-650. On some chalices, Mary was depicted with what appears to be a Eucharistic cloth, or episcopal pallium, or other priestly insignia, hanging from her waist. ${ }^{20}$ For one example, see Fig. 5.1. Dora PiguetPanayotova suggests that this particular insignia, hanging from beneath Mary's maphorion, represented a belt such as an Artemis priestess might have worn. ${ }^{21}$ It might alternatively represent the insignia of a Christian woman priest. For youthful Jesus holding a large book on the opposite side of the same chalice, see Fig. 5.2.

Censers for incense were used during the liturgy, and many of these also depicted Jesus and Mary on opposite faces, including one of the three unstamped silver censers found with the chalices in the 


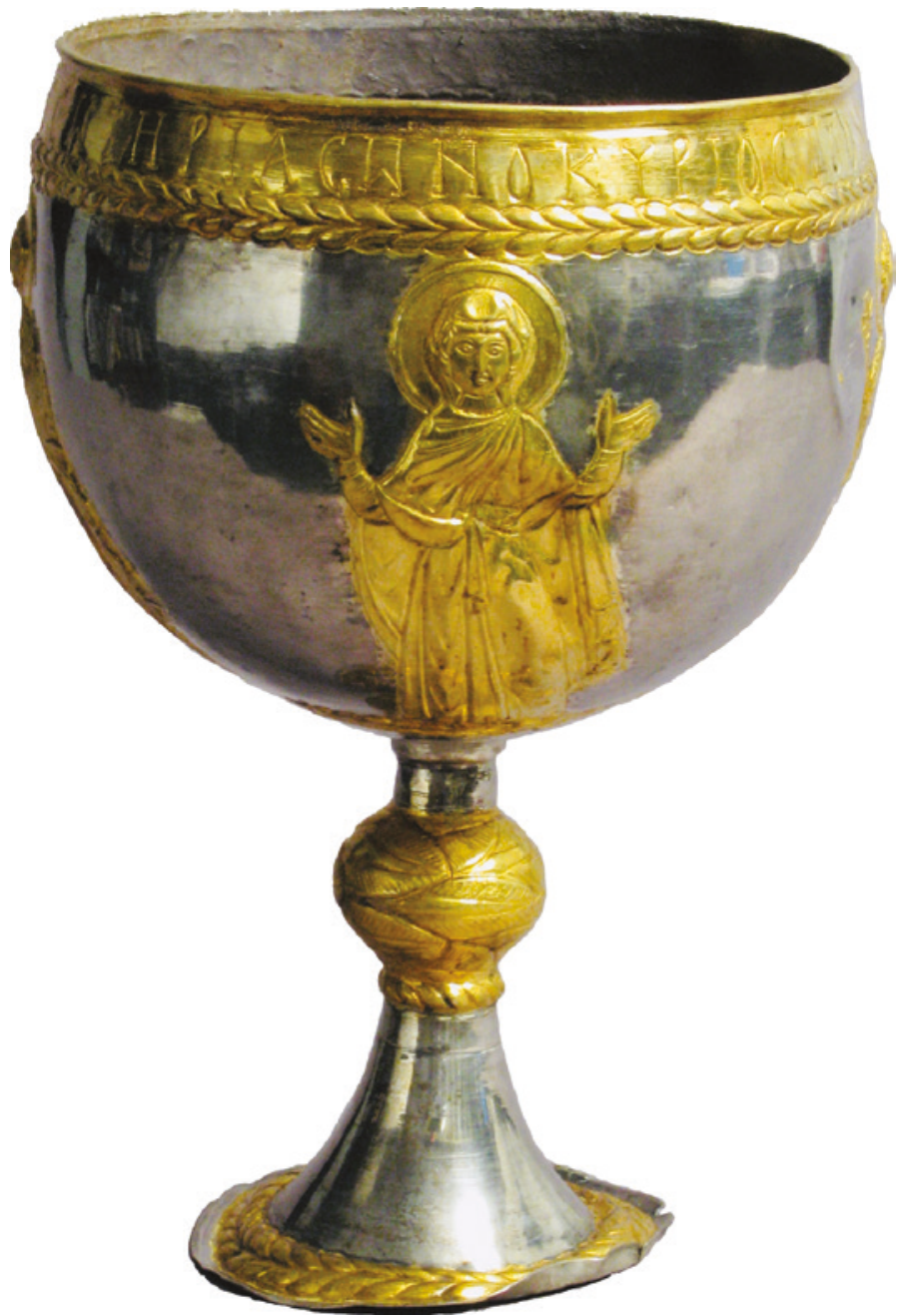

Fig. 5.1 Mary with priestly insignia hanging from her girdle. Unstamped silver chalice usually dated 500-650. Attarouthi Treasure, northern Syria. Metropolitan Museum of Art, New York City. Purchase, Rogers Fund and Henry J. and Drue E. Heinz Foundation, Norbert Schimmel, and Lila Acheson Wallace Gifts, 1986. Accession no. 1986.3.7. CC0

Attarouthi hoard. ${ }^{22}$ Other censers that paired mother and son are in the British Museum and the Bayerisches Nationalmuseum in Munich. ${ }^{23}$ A hexagonal censer probably made in Constantinople that portrays Mary, 


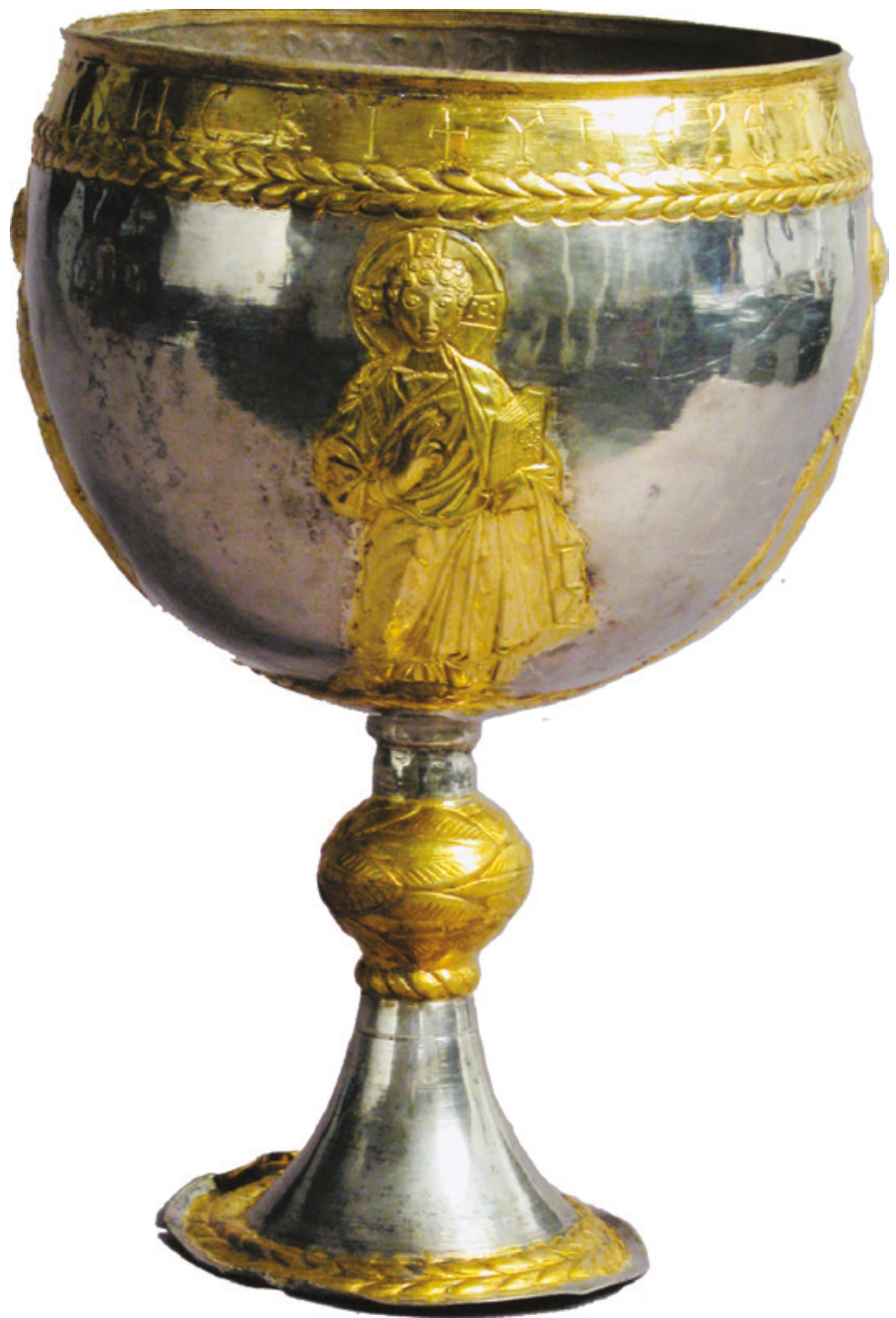

Fig. 5.2 Boyish Jesus holds a large book (opposite side of chalice)

arms-raised, is also in the Metropolitan Museum of Art in New York City, but from a different hoard. It has silver stamps, which securely date it between 582 and $602 .{ }^{24}$

Other items likely used in the liturgy, or associated with the altar, paired Mary and Jesus. The silver Homs ewer in the Louvre Museum probably was used to hold the wine. It does not have silver stamps and 
therefore is broadly dated sixth to seventh century. ${ }^{25}$ Two silver reliquary boxes have survived that paired mother and son, neither of which depicts Mary with her arms raised. One, in the Kunsthistorisches Museum in Vienna, portrays Mary holding an open book. It was found near Pola, Croatia, and is unstamped, therefore broadly dated sixth or seventh century. ${ }^{26}$ The other box, in the State Hermitage Museum in St. Petersburg, shows only Mary's face. It has silver stamps dating it between 527 and $547 .{ }^{27}$

Christians used holy oil continuously from the beginning. The canonical gospels describe women anointing Jesus (Matt 26:7, Mark 14:3, Luke 7:37-38, John 12:3), as well as apostles (Mark 6:13) and presbyters (James 5:14-15) anointing the sick. Some second-century writers described baptismal anointing. ${ }^{28}$ This rite appears to be described in a fragment of the Thecla narrative: "Thekla gave them instruction, teaching them the Gospel of God and, anointing them with the oil of gladness, she baptized them." 29 An unstamped silver flask that probably held such oil was excavated in Syria, an area where anointing was prominent as part of the baptismal ritual. ${ }^{30}$ Today this silver bottle is in the Walters Art Museum in Baltimore. It has no silver stamps but is dated to the same period as liturgical utensils with stamps, from 500 to 670 . Like objects others mentioned above, this flask also depicts Jesus on one side and his mother on the opposite side. Here, a boyish Jesus carries a book. Mary, arms-raised, wears a type of cloth insignia hanging from beneath her girdle. Between them are two arms-raised saints, one with long curly effeminate hair (a female saint?) and one with short hair ${ }^{31}$ (see Fig. 5.3a, b).

Mother and son were also paired on silver processional crosses. With respect to these large crosses, Maria Mundell Mango says it is important to distinguish between crosses and crucifixes, because crucifixes, which bear the body of Christ, do not appear until the Middle Byzantine period. ${ }^{32}$ Before then, Mary is often found in the center of the cross, and she continues to be even during the transition to crucifixes. For example, a medieval silver cross in the Musée de Cluny has several scenes from Mary's life on it, including Mary holding her infant in the center of it; in another example, a copper cross in the Benaki Museum in Athens depicts Mary arms-raised in the center of the front of the cross and Jesus in a loincloth on the back. ${ }^{33}$ A large number of small wearable pectoral crosses in the same style-Mary arms-raised on the front and Jesus on the back-have survived from the Middle Byzantine period. ${ }^{34}$

Another example of an earlier silver processional cross with Jesus and Mary on it is the Caginkom Cross in the Archeological Museum of 

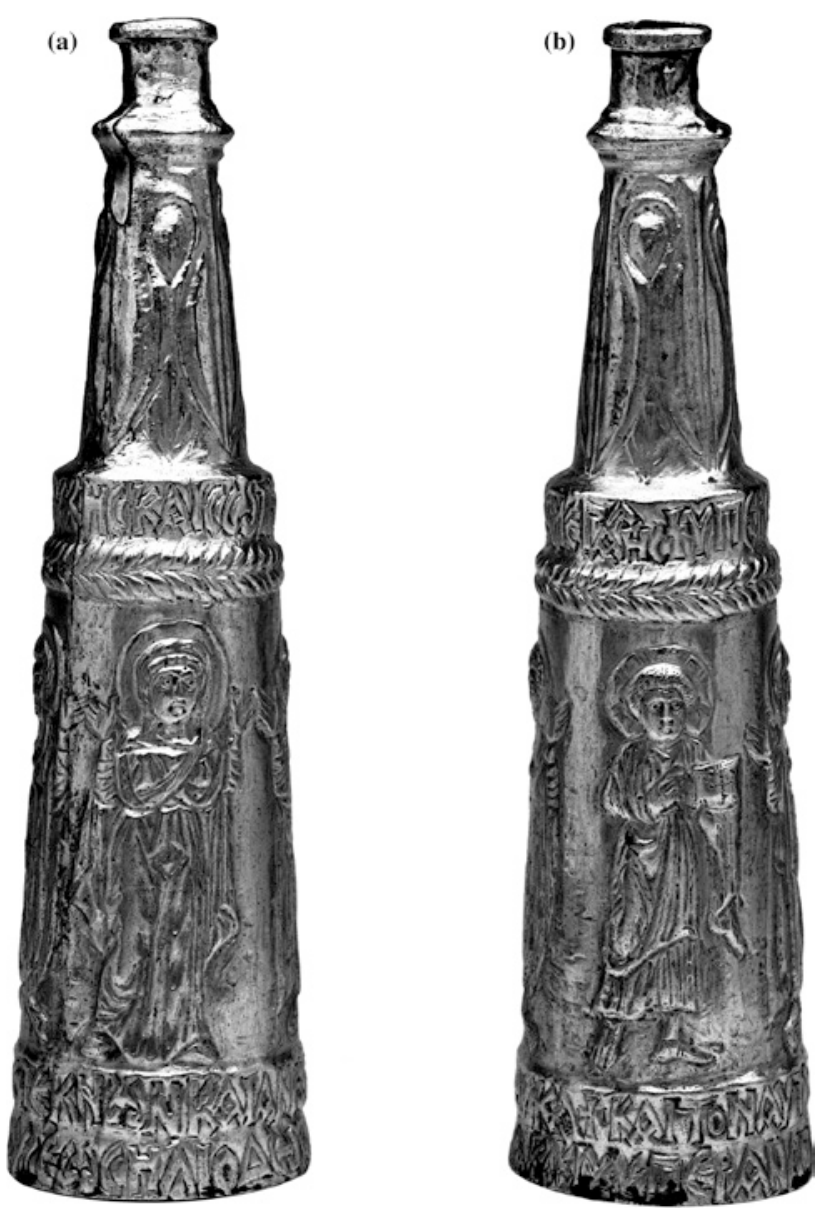

Fig. 5.3 a Mary and Jesus paired on silver flask for holy oil. Cloth insignia hangs from Mary's girdle. b Boyish Jesus holds gospel book. Unstamped silver flask usually dated 550-600. Hama Treasure from Ancient Syria. The Walters Art Museum, Baltimore, accession no. 57.639. CC0

Istanbul. It has silver stamps that date it between 527 and $547 .{ }^{35}$ The portrait of Mary is featured in the center of the cross. A portrait of Jesus is above Mary, at the top. The portrait of a female saint is below Mary, at the bottom. Portraits of archangels are at the ends of both arms of the cross. $^{36}$ 
Another silver processional cross depicts Mary, arms-raised, inside the center medallion on one side and Jesus, stepping out of his sarcophagus, inside the center medallion on the other side. This is the stational cross of Bishop Agnello in the Archbishop's Museum in Ravenna. It does not have silver stamps to date it, but is usually considered sixth century ${ }^{37}$ (see Fig. 5.4).

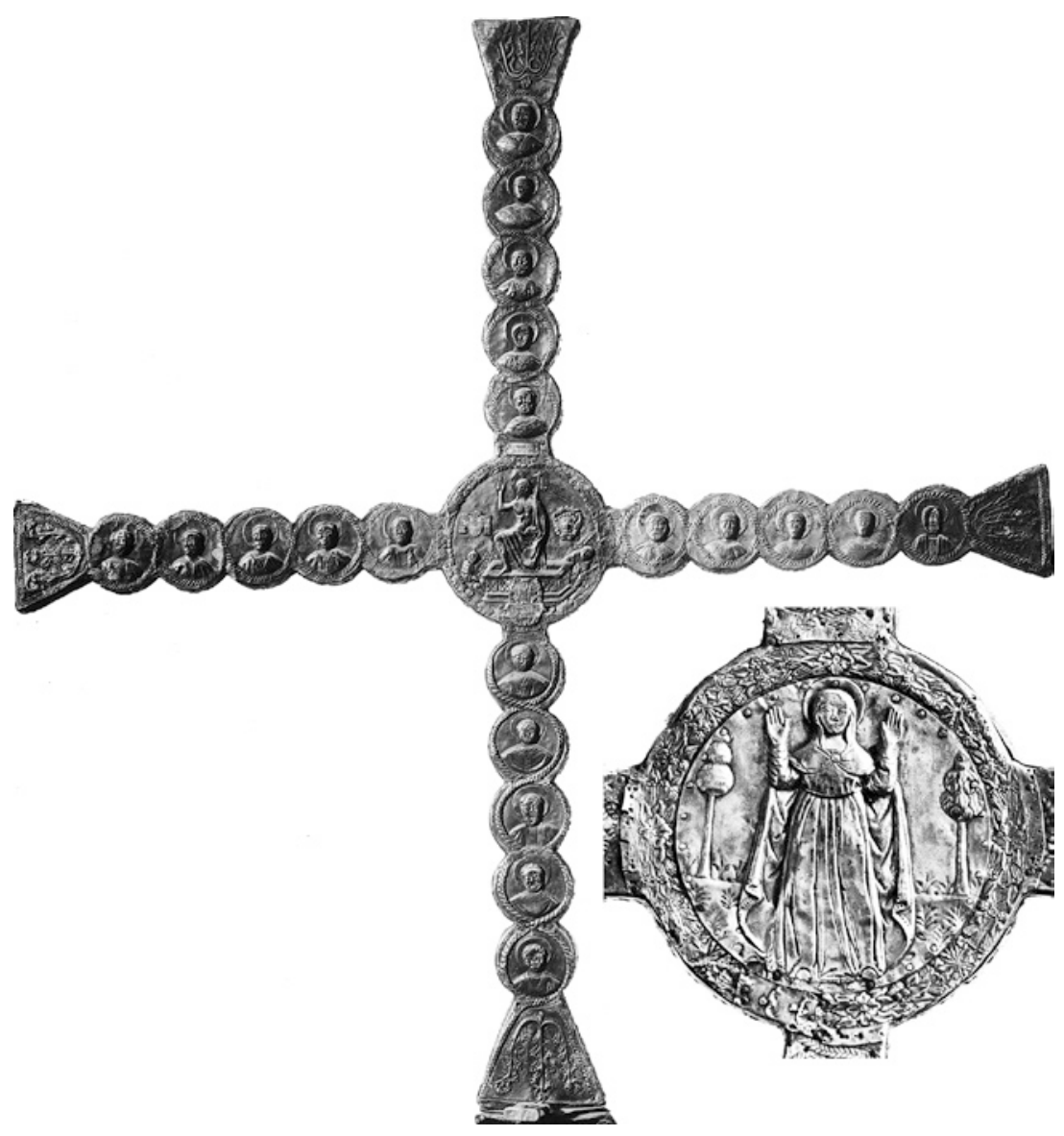

Fig. 5.4 Jesus in center medallion. Inset: Mary on opposite side. Unstamped silver processional cross usually dated 500s. Archbishop's Museum, Ravenna. (C) Alinari Archives-Alinari Archive, Florence 
Two sixth-century sets of ivory book covers, likely used for the gospels, also paired Jesus and Mary. ${ }^{38}$ One set, the Saint-Lupicin covers, is today in the National Library of France. The other, called the Etchmiadzin gospel covers, is in the Mantenadaran in Yerevan, Armenia. One cover on both sets has a portrait of Mary holding her baby, which is surrounded by four scenes from her life. The opposite cover has a portrait of Jesus, which is surrounded by four scenes from his life. Two scenes from the Protevangelium are on both of the covers with Mary. One scene depicts Mary holding a wide bowl at the Test of Bitter Water. The other depicts Mary holding a spindle for her weaving. The iconography of Mary is similar on both, but on the SaintLupicin covers, the artist depicted Jesus bearded like an old man-a later motif. The Etchmiadzin Gospel covers, however, portray Jesus as a beardless youth, which is characteristic of the oldest Christian art. For Mary on the Etchmiadzin gospel covers, see Fig. 5.5a. For Jesus, see Fig. 5.5b.

(a)

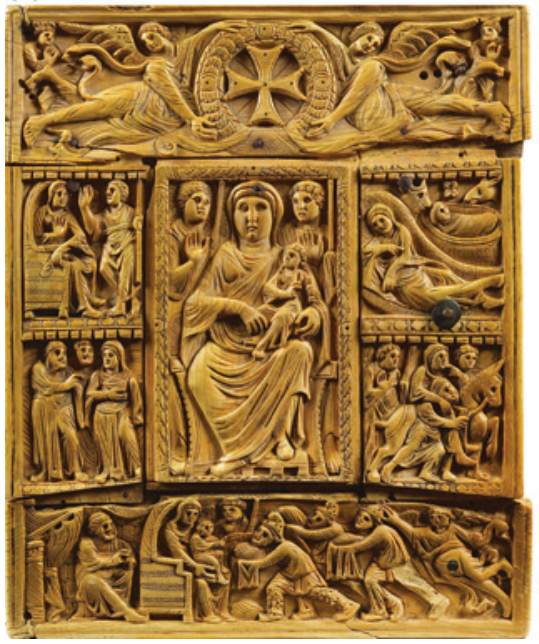

(b)

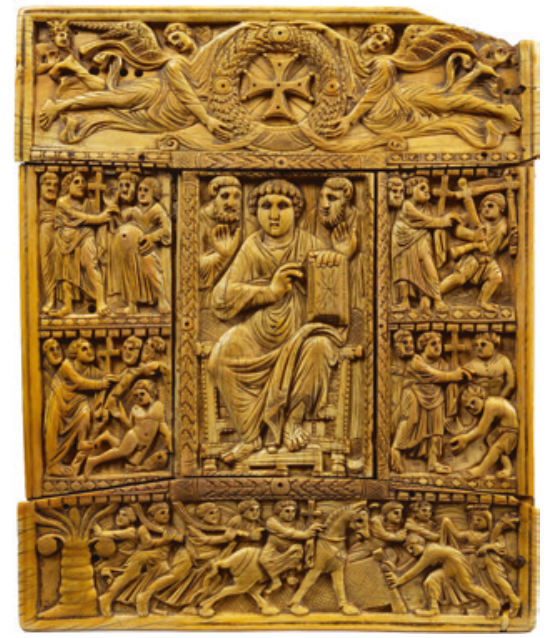

Fig. 5.5 a Mary on ivory gospel cover. b Jesus on opposite cover. Etchmiadzin gospel covers, usually dated 550-575. Mantenadaran, Yerevan, Armenia. Courtesy (C) Hrair Hawk Khatcherian 
The pairing of scenes from Jesus and Mary's respective lives is also on some gold pectoral medallions. A pectoral medallion like this is called an "encolpion." It signifies episcopal authority and is worn hanging from the neck of the bishop. One encolpion dated circa 600 and unearthed in Adana, near Tarsus, is today in the Archeological Museum of Istanbul. One face has several small scenes featuring Mary-Annunciation, Visitation, Nativity, the ride to Bethlehem, and the Adoration of the Magi (the wise men bearing gifts). The other face has seven small scenes of Jesus's healings, miracles, and ministry. ${ }^{39}$ Yet another encolpion, dated 584 and unearthed in Cyprus, is now in the Dumbarton Oaks Collection. One face portrays Mary holding her infant, plus two small scenes of the Nativity and the Adoration of the Magi. The other side comprises a large scene of the baptism of Jesus. ${ }^{40}$

The most interesting gold encolpion is in the State Museum of Berlin. It is nearly identical in shape to the other two, although it has a more ornate setting. Its front face depicts Mary holding a spindle for her weaving in accordance with the Protevangelium. Its back face depicts Jesus at the miracle of Cana and is entitled, "The first miracle." 41 The encolpion probably hung from a large, ornate gold pectoral made by the same goldsmith, which has an inscription, "Lord help the wearer"-with the word "wearer" in the feminine gender-and, so, according to Marvin C. Ross, "This pectoral must have been made for a woman." 42 This encolpion is rarely identified as an encolpion, apparently because it hung from a pectoral which was worn around a woman's neck ${ }^{43}$ (see Fig. 5.6).

Jesus and Mary sometimes were paired in church decoration. For example, the early fifth-century wood panel on the door of the Santa Sabina Church that depicted Mary with her arms raised beneath Jesus, in the Six Books scene of her death and ascension, was paired with a second, adjacent, wood panel that depicted Jesus's own ascension. ${ }^{44}$ In another example, around the year 500, King Theodoric installed monolithic mosaics of Mary and Jesus seated on thrones facing each other across the nave on opposite sides of the altar apse in Sant'Apollinare Nuovo Basilica in Ravenna. ${ }^{45}$ Along the walls of the nave, twenty-two women and three magi bearing gifts process toward the portrait of Mary, while on the opposite side, twenty-six men process toward Jesus. The mosaics of these saints date approximately sixty years later than the mosaics of Jesus and Mary and may have replaced older mosaics of earlier saints. ${ }^{46}$

Another pairing of Mary and Jesus on thrones is on the late fourth-century San Nazaro silver reliquary box in Milan, which features 


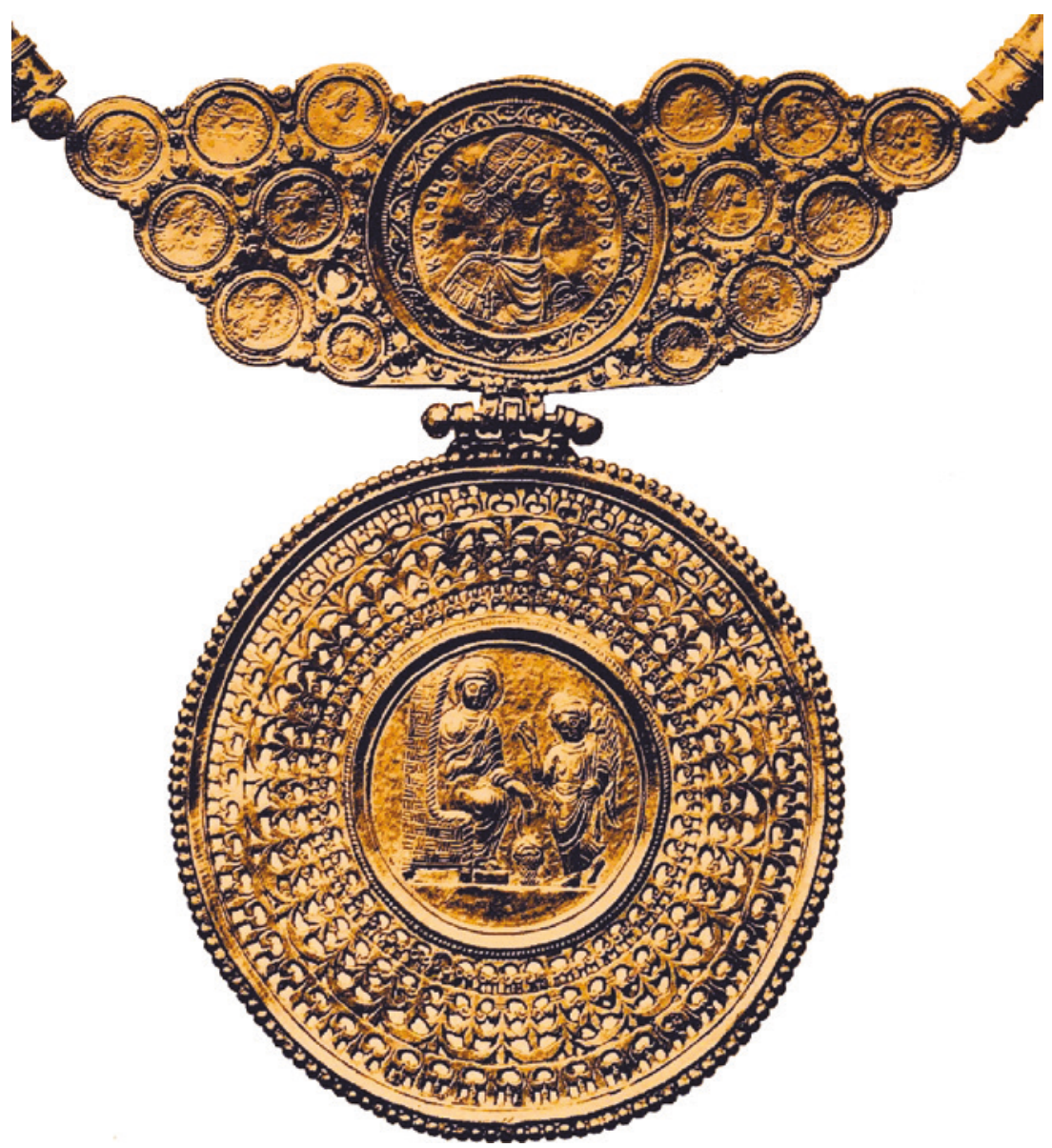

Fig. 5.6 Gold encolpion-Mary at Annunciation. Pectoral inscription: "Lord help the wearer (f)." 600s. Dennison, Gold Treasure, pl. 17

a portrait of Mary flanked by two men, each of whom carries a large platter or paten. A portrait of Jesus as a young man is on its lid. Until recently, this silver reliquary box confounded some modern art historians and instigated quite a dispute over its dating. Excavated in 1896 from late fourth-century strata beneath the high altar of the Roman era church of San Nazaro, some scholars refused to concede that the age of 
(a)

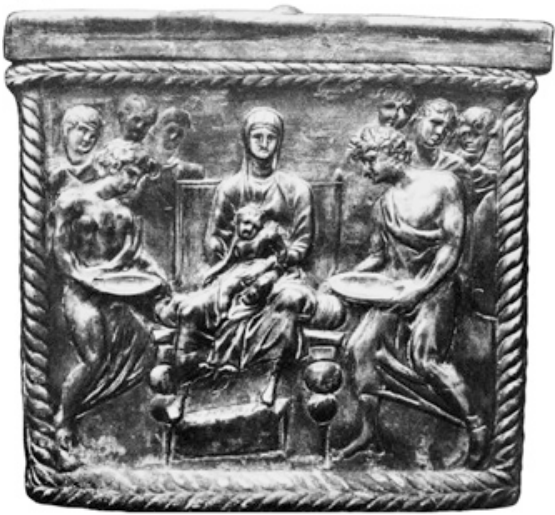

(b)

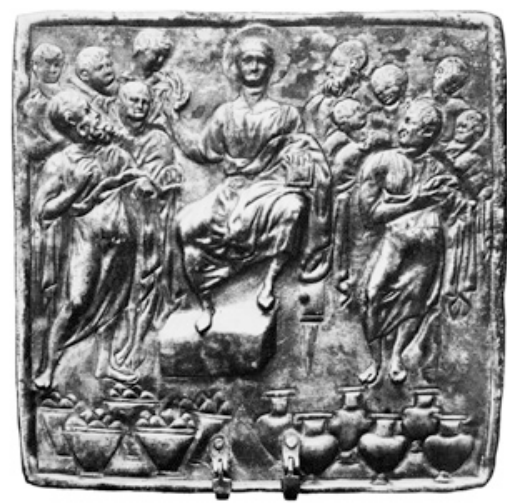

Fig. 5.7 a Mary on front. b Jesus on lid. San Nazaro silver reliquary box, ca. 380, Milan. Wilpert, Römischen Mosaiken, figs. 338 and 363

the reliquary box could possibly match its strata. On the box, Mary sits on a throne larger than the one upon which her grown son was seated, and these scholars argued that this elevation of Mary meant the box must be much later-some scholars argued it was a late nineteenth-century forgery. A recent technical investigation, however, decisively demonstrated that the box indeed was manufactured around the year 380, the same dating as the strata in which it was discovered under the altar ${ }^{47}$ (see Fig. 5.7a for Mary on the front and Fig. 5.7b for Jesus on the lid).

\section{Dividing the Mother-Son Dyad: The Maria Maggiore Mosaics}

The dating controversy around the late fourth-century San Nazaro silver reliquary box, which continued until the recent technical investigation demonstrated that, indeed, the box was the same date as its late fourth-century strata. The late fourth-century dating of this silver reliquary box suggests that other Marian artifacts pairing mother and sonmany of which have not been technically investigated-may also be older than currently dated. An example of such artifacts that are usually dated sixth century or later-but which could be older-are the unstamped silver chalices for the Eucharist, as well as other unstamped silver pieces associated with the liturgy that paired Mary and Jesus. 
Between the years 500 and 670 , silver was stamped with the reign of the emperor. If a silver object is stamped, it can be securely dated to the years during which that emperor reigned. Maria Marlia Mango did a study which, remarkably, indicated that only around a quarter of all silver pieces associated with the liturgy have silver stamps. Furthermore, the iconography of the unstamped pieces associated with the liturgy is substantially different than the iconography of the stamped pieces. For example, stamped objects seldom have figural decoration (such as images of Jesus and Mary). None of the silver chalices that paired Jesus and Mary were stamped. ${ }^{48}$ In addition, unstamped objects tend to have portraits of Jesus as a beardless boy without a cross-much like he was depicted in the Christian catacombs of Rome. ${ }^{49}$ Finally, unstamped silver pieces associated with the liturgy rarely have large crosses as part of their design, whereas the stamped silver pieces do. ${ }^{50}$ The lack of large crosses suggests that the unstamped pieces could be older, because the cross is virtually never seen in Christian art prior to the end of the fourth century and afterward only slowly became a featured motif.

Could unstamped silver liturgical objects that pair Mary and Jesus be older than the stamped pieces? That is, could they have been made prior to the year 500, when silver stamping began? There appears to be no reason that they could not be older. Yet, as the dating controversy around the San Nazaro silver reliquary box illustrates, modern art historians typically date objects that depict Mary later, to the sixth century, and beyond.

This late dating of Marian artifacts began with the old hypothesis that when the church fathers at the Council of Ephesus in 431 called Mary the "Theotokos," they caused a gradual explosion of Mariology. ${ }^{51}$ This hypothesis assumes that Mariology would have taken a few decades to blossom and that therefore, with little exception, almost all Marian artifacts must have originated after the year 500. In circular fashion, this late dating of Marian artifacts then becomes evidence used to validate the original hypothesis.

Until recently, most scholars accepted the hypothesis that the bishops at the Council of Ephesus in 431 essentially caused Mariology by using the title Theotokos for Mary. Recently, some scholars have delicately pointed out that this title was already in use for Mary. ${ }^{52}$ Long before the Council of Ephesus, at least as early as the Council of Nicaea in 325, some bishops were already calling Mary "Theotokos," and they were calling her that without any definition or explanation. According to Richard Price, "The use of the word is incidental: it is not explained or justified, and no weight is placed upon it. The implication is that 
by the time of the Council of Nicaea in 325 the term was already in standard use." 53 The earliest undisputed use of Theotokos for Mary is in 319, when Bishop Alexander of Alexandria used Theotokos for Mary. ${ }^{54}$ Decades before the Council of Ephesus, some of the most influential people in the Empire-from the famed Trinitarian theologian Athanasius (296-273) to the pagan Roman Emperor Julian "the Apostate" (330-363 $)^{55}$ —are recorded calling Mary the Theotokos. Additional evidence indicates the title was used for Mary in the third century. ${ }^{56}$

Consistent with the early use of Theotokos for Mary, literature that elevated Mary, such as the Protevangelium and the Dormition narrative, which portrayed Mary as someone who, like her son, was born without a man's seed and bodily taken up to heaven, was composed centuries before the Council of Ephesus. ${ }^{57}$ Finally, as we saw earlier in Chapter 2, after the Council of Ephesus, some scribes were not elevating Mary, they were demoting her-they were excising passages that portrayed her with liturgical authority.

Recently, some scholars have questioned the validity of the old hypothesis that the Council caused Mariology. ${ }^{58}$ A false premise has kept the old hypothesis alive. That false premise is that the triumphal arch mosaics in the huge Maria Maggiore Basilica in Rome elevated Mary. Since these mosaics were completed shortly after the Council of Ephesus, they are presented as evidence that, nonetheless, somehow, the Council must have kicked off Mariology. Over the decades, however, some art historians have quietly concluded that the Maria Maggiore mosaics do not elevate Mary as the Theotokos. ${ }^{59}$

The first clue that the Maria Maggiore Basilica mosaics were not designed to elevate Mary as Theotokos is that the basilica's dedicatory inscription did not call her Theotokos. Nor did the inscription call Mary by her equivalent Western title, Mother of God. Instead, Sixtus III dedicated the basilica to Virgo Maria - the Virgin Mary. ${ }^{60}$

The second clue that the mosaics were not intended to elevate Mary is that Mary was not depicted with a halo in these mosaics. King Herod overseeing the Massacre of the Innocents has a halo-but not Mary. Certainly, a halo for Mary was a design option, because much older fourth-century gold glass from the Christian catacombs of Rome depicted a woman usually identified as Mary ${ }^{61}$ —an arms-raised woman with MARIA or MARA written over her head ${ }^{62}$ —with a halo. For two examples, see Fig. 5.8. 

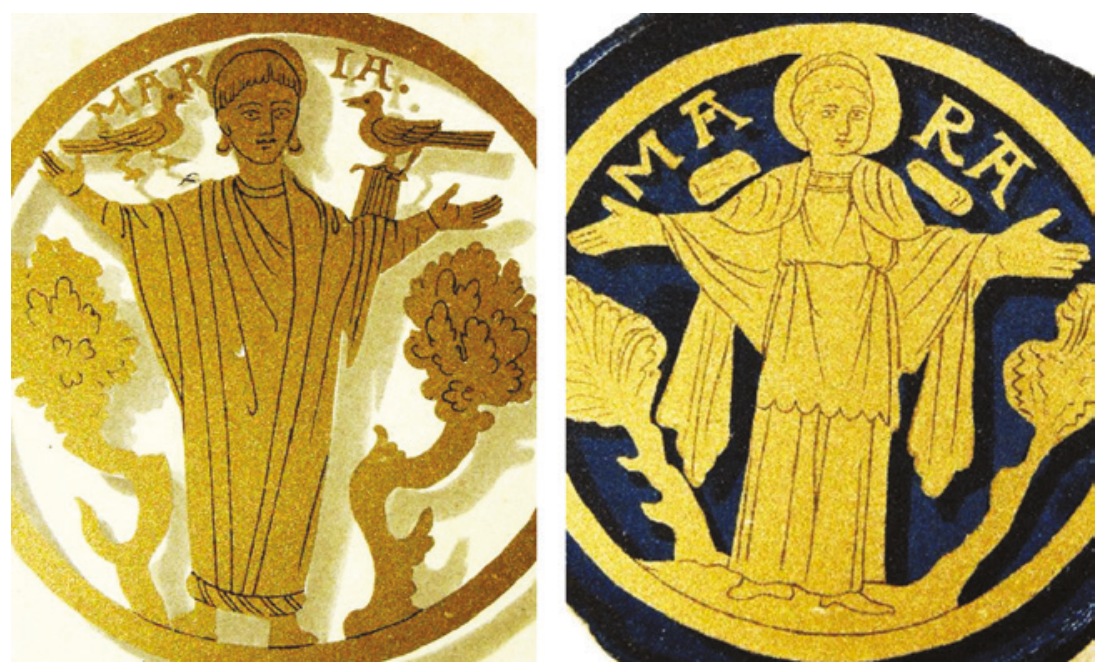

Fig. 5.8 Mary with halo. Late 300s gold glass from the Christian catacombs, Rome. Perret, Catacombes de Rome, pl. 4:21.1 and 7

The third clue that these mosaics were not intended to elevate Mary is that the scene of the Adoration of the Magi (the wise men bearing gifts) was unique, never seen before and never seen again. Instead of elevating Mary's motherhood, as was typical in older scenes of the Adoration of the Magi, the mosaic designer de-coupled mother and son. For the first time, the child was seen seated alone on a huge throne, his mother divided into two women seated on either side of him, neither touching him, much less holding him. This scene is so extraordinarily peculiar that Beat Brenk calls it "the most unusual scene in Early Christian art."63

Before viewing the Maria Maggiore mosaic of the Adoration of the Magi, it is important to first view older artifacts of the Adoration of the Magi in Rome, because this iconography was very popular, with dozens of older examples still in existence. ${ }^{64}$ The Maria Maggiore mosaics broke with the way earlier artists - as well as later artists— portrayed Mary's relationship with her son. The older iconography almost universally portrayed Mary holding her son on her lap. For example, an early fourth-century fresco in the Petrus and Marcellinus catacomb in Rome portrays Mary holding him on her lap while she is seated on a tall round-backed chair. They are flanked by two men holding out platters ${ }^{65}$ (see Fig. 5.9). 


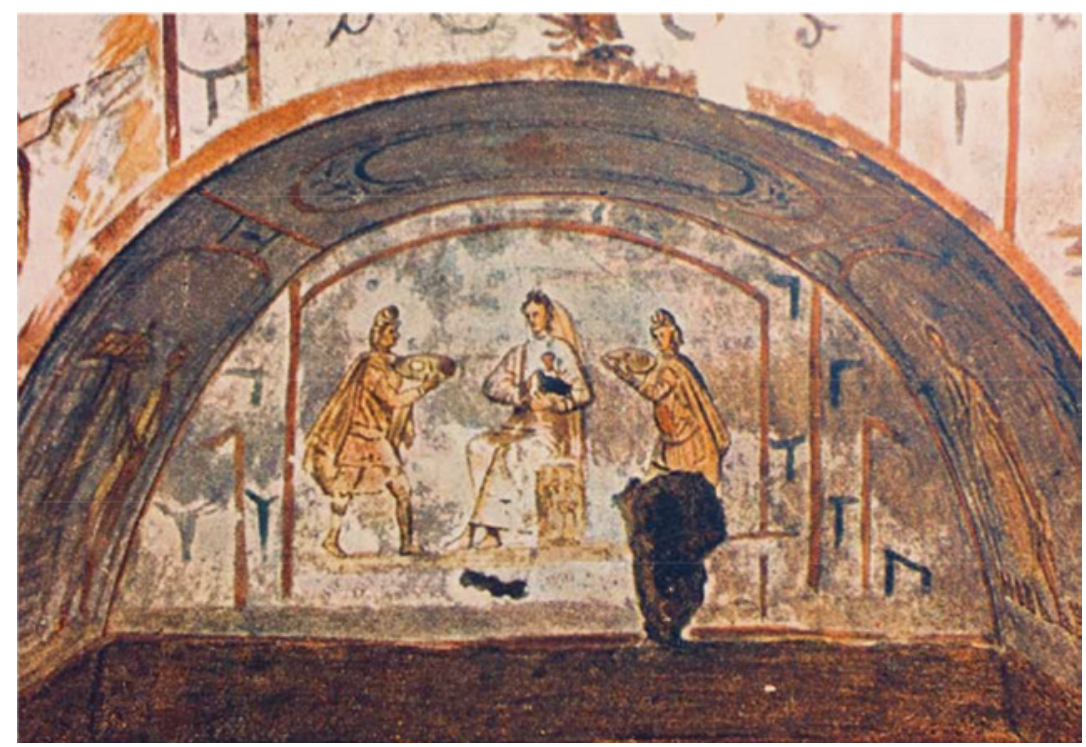

Fig. 5.9 Mary holds her son. Two magi bring platters. Early 300s fresco of the Adoration of the Magi, Rome. Wilpert, Malereien, pl. 60

Although today we are accustomed to three men bearing gifts, neither Matthew, nor Luke nor the Protevangelium, specifies how many magi came. Early Christian artists portrayed two to four magi. These wise men were almost always dressed as Phrygians with colorful tunics, leggings, and floppy, peaked caps. In addition, their gifts were often depicted as large round platters, as if for communion bread, sometimes with tiny pieces on the platter, also seen in Fig. 5.9.

In the context of the scene of the Adoration of the Magi in the Maria Maggiore mosaics, the most important comparative example is a wood panel on the doors of Santa Sabina Basilica dated 420-430 - it thus was carved only a few years before the Council of Ephesus. Here, the gifts appear to be round flat loaves of bread, and the one offered by the first magi is even etched with a large four-sided cross, as if for the communion. This wood sculptor literally elevated Mary. She is carved seated atop six steps, holding her infant son, herself the seventh, holy, level (see Fig. 5.10). 


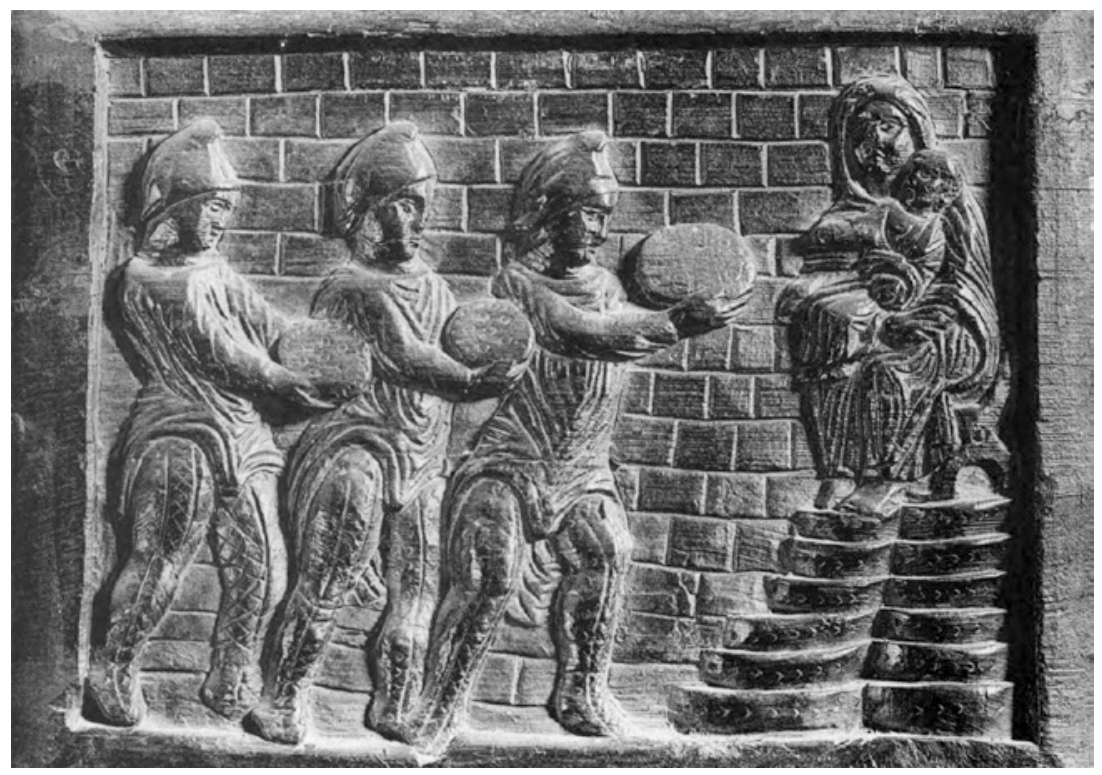

Fig. 5.10 Mary holds her son, elevated. Three magi bring platters. 420-430, Santa Sabina Basilica, Rome. Wiegand, Altchristliche, pl. 13

Santa Sabina Basilica was constructed under Pope Celestine (r. 422432), who died almost immediately after the Council of Ephesus, before news of the council reached Rome. Clearly, as this wood panel demonstrates, even before the Council of Ephesus he was comfortable with art that elevated Mary. He may have been the pope who began construction of the huge Maria Maggiore Basilica dedicated to Mary. Although two inscriptions identify the next pope, Pope Sixtus III (r. 432-440), as the pope who completed Maria Maggiore, archeological evidence related to its construction indicates that Pope Celestine may have started it. Maria Maggiore's construction method is the same as Santa Sabina'sand different than any church built in the decade after Celestine died. ${ }^{66}$ Thus, if Pope Celestine had lived just a few more years, we might today see an Adoration scene in Maria Maggiore like the one carved on the Santa Sabina wood panel. Instead, we see a completely novel scenethe scene that Brenk calls "the most unusual" in early Christian $\operatorname{art}^{67}$-a scene where the infant Jesus sits by himself on a huge throne, a scene 
that divides his mother into two women seated on either side of him, one dressed in gold, one in black, neither touching him. It is as if the child has two mothers, yet no mother at all. Which of the two parallel women beside the infant represents his mother-and who is the second woman?-is still debated ${ }^{68}$ (see Fig. 5.11).

Here again, we see the magi dressed as Phrygians with their floppy caps and tunics, carrying large round platters laden with what appears to

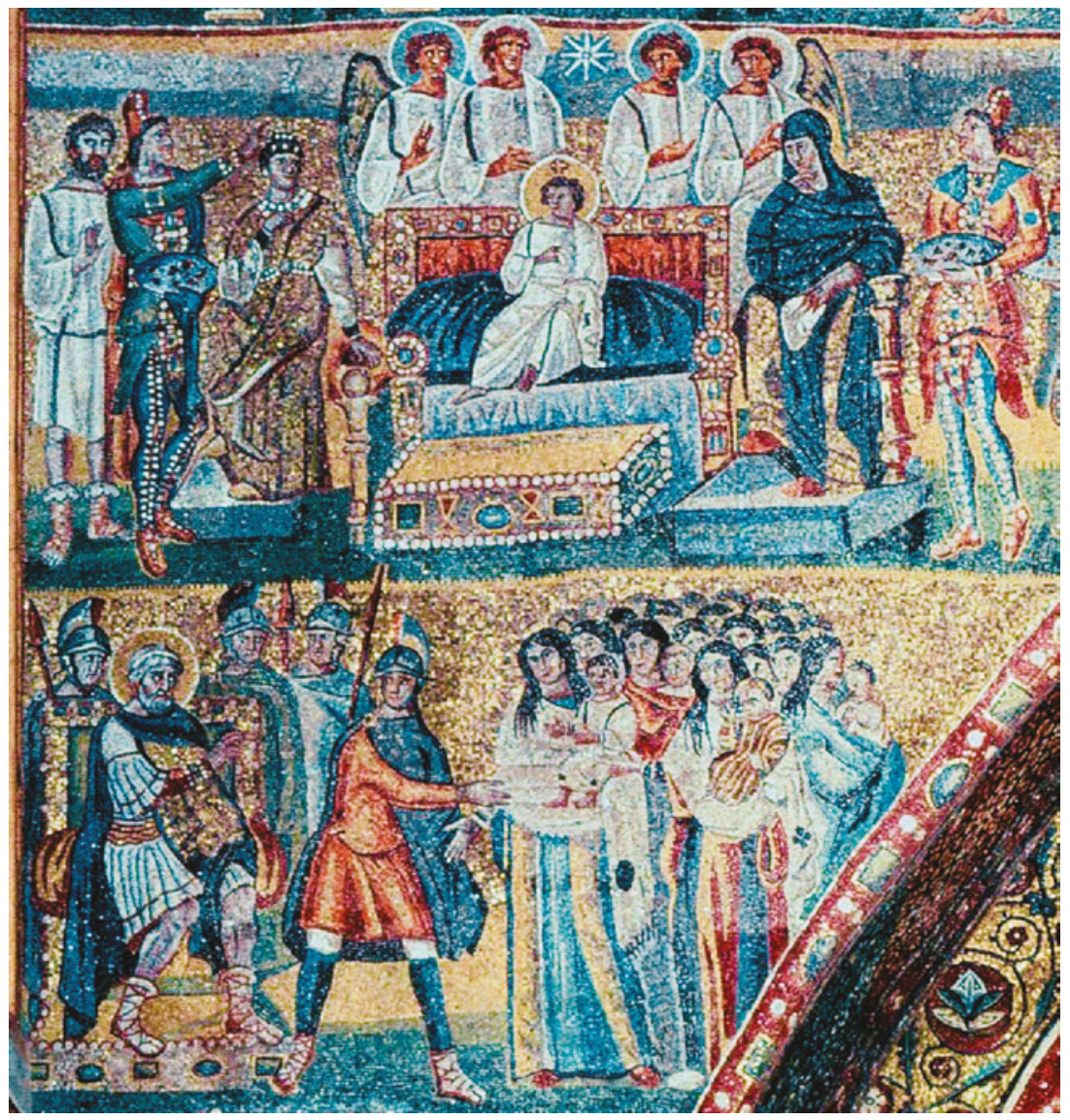

Fig. 5.11 Top: Adoration of the Magi. Child sits alone. Two women flank him. Below: Herod with halo, directing soldiers. 432-440. Maria Maggiore Basilica. (C) DeA Picture Library, concesso in licenza ad Alinari 
be pieces of bread. Yet here Mary does not hold her son. Cleo McNelly Kearns describes mother and son in older scenes of the Adoration of the Magi as a "unity" or "the mother-son dyad." 99 Here, the mosaic designer divided the mother-son dyad. This strange composition of the Adoration of the Magi suggests that the patron of these mosaics did not intend to elevate Mary or her motherhood. Not only is the mother-son dyad divided, but also we cannot even tell for certain which woman is his mother. Further signifying Mary's demotion, neither of these women has a halo. Yet directly below them, King Herod-in the scene where he orders his soldiers to kill all the male children who were under two years old (Matthew 2:16) - has a large yellow halo.

Three more mosaic panels on the triumphal arch depict Mary, always without a halo. One, an Annunciation scene that portrays her weaving, a scene from the Protevangelium, naturally does not have her son in the scene with her because he was not yet conceived. The two that do depict her son with her further demonstrate that the patron of these mosaics wanted to symbolically demote Mary's motherhood in the public eye.

Only one mosaic panel shows Mary actually touching her son. That panel is top right, high above the floor of the nave. In addition to the height, it is hard to identify Mary in it because she is off center and smaller than the people who are in the center. ${ }^{70}$ In the panel directly below this one, Mary is even further off center. In this scene, as in the scene of the Adoration of the Magi, Mary does not hold her son. Again the mother-son dyad is divided. A man was placed standing between Mary and her son. As if that were not enough to convince the laity in the nave that Mary was not all that important, the panel below again depicts Herod, with his big halo, directly below Mary-a positioning that appears to be intended to highlight that even compared to Herod the babykiller, Mary herself is not holy enough or regal enough-or Theotokos enough-to have a halo. ${ }^{71}$

One final detail strongly suggests that the patron of these mosaics wanted Mary to literally disappear. In all four registers, Mary is dressed in gold against a gold mosaic background-which makes her disappear into the background, as seen in Fig. 5.11. Some scholars propose that Mary dressed in gold suggests her elevation, either divine or imperial. ${ }^{72}$ Yet Mary does not have a halo, nor, as Maria Lidova notes, does she have a crown..$^{73}$ Regardless why Mary was dressed in gold, the designer of these mosaics almost certainly knew that dressing Mary in the same gold color as the gold background would make her form disappear. 
In conclusion, the premise that the Maria Maggiore mosaics elevate Mary is false. When compared with depictions of Mary in older artwhether on gold catacomb glass or in older scenes of the Adoration of the magi-it is apparent that the design of the Maria Maggiore mosaics was not intended to elevate her. The overall design of the mosaics appears to signify a powerful opposition to Mary as Theotokos-at least in the city of Rome at that moment in time.

This opposition, however, like the pope himself, was transitory. The strange iconography of the Adoration of the Magi is never seen again in art, despite that it was prominently displayed in one of the four largest basilicas in Christendom. Instead, art that elevated Mary continued to be installed in Rome. For example, around the year 700, Pope John VII installed a monumental mosaic cycle of Mary's life in his oratory in Old Saint Peter's Basilica, a cycle which included the Adoration of the Magi. Here, the laity saw the mother-son dyad the same way we see it in catacomb art: Mary seated on a large chair, her son on her lap, the magi bringing gifts. ${ }^{74}$

It is uncertain whether the papal patron behind the Maria Maggiore mosaics was Pope Sixtus III or his archdeacon, the future Pope Leo the Great. ${ }^{75}$ Whoever it was, in Chapter 7 below, I provide a plausible reason for his opposition to Mary as Theotokos. For now, suffice it to say that his opposition almost certainly was related to the dispute that led to the Council of Ephesus in the first place- a conflict between Nestorius, the new patriarch of Constantinople, and the Augusta, the Princess Pulcheria, who herself invoked Mary the Theotokos. ${ }^{76}$

\section{The Mother-Son Dyad in Art Prior TO The Council of Ephesus}

Silver stamps on a handful of liturgical objects, such as some censers, prove that some Christians continued to pair Mary and her son into the seventh century. The late fourth-century San Nazaro silver reliquary box demonstrates that some Christians were already pairing mother and son in the late fourth century. A second fourth-century reliquary box adds to the accumulation of evidence that artists were pairing them well before the Council of Ephesus. ${ }^{77}$

In the early 1970s in Novalje, near the city of Zadar in modern Croatia, someone digging in their courtyard discovered a copper-sheathed 
reliquary box that was buried along with other objects typical of the fourth century. ${ }^{78}$ The Novalje box was covered with thin sheets repetitively stamped with two tiers of frames depicting ten scenes, five from Hebrew scripture and five from the gospels. This iconography is consistent with that of fourth-century frescos and gold glass from the Christian catacombs of Rome, including the way that the letters of names are sometimes in sections on both sides. A boyish shepherd titled with the word for shepherd in Latin, PASTOR, is in the middle of the gospels scenes. ${ }^{79}$ On this unquestionably Christian artifact, the shepherd almost certainly represents Jesus, who, in John 10:11-21, said, "I am the good shepherd." Next to the shepherd is an arms-raised woman with Mary's name in Latin on either side of her head, MARIA. Here, Mary as the arms-raised woman and Jesus as the shepherd function as counterparts (see Fig. 5.12).

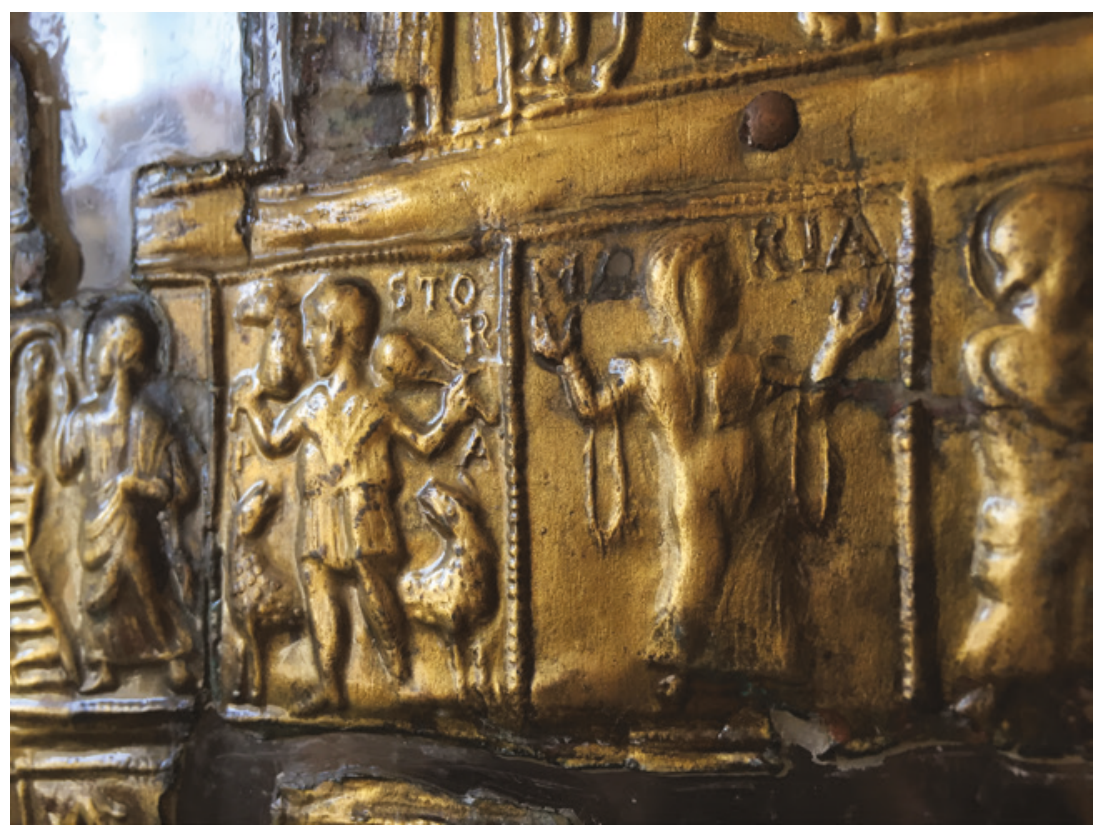

Fig. 5.12 PASTOR and MARIA. Novalje Reliquary Box, late 300s. Courtesy David Edward Kateusz and Archeological Museum Zadar 
The Novalje reliquary box is in the Archeological Museum of Zadar. A recent reconstruction overseen by the museum's director, Jakob Vučić, indicates that this image of MARIA originally appeared ten times around the sides and lid. This stamping presupposes a mold and suggests mass manufacture. Given the amount of trade around the Mediterranean during the fourth century, it is impossible to say where the mold, or the stamped sheathing, or even the box, originated. Nonetheless, the mass production implicit in its mode of manufacture suggests that the pairing of mother and son was common in art.

This secure identification of Mary as the arms-raised woman in this fourth-century pairing means that with some confidence, we can also identify similar pairs of an arms-raised woman and a shepherd as symbolizing Mary and her son. A pairing similar to that on the Novalje box is on a fourth-century sarcophagus found near Arles in Ancient Gaul, today in the Museé de l'Arles antique. On the Novalje box, the shepherd and arms-raised woman named MARIA are side-by side and flanked by frames depicting gospel scenes. On this sarcophagus front, they also are side-by-side and flanked by gospel scenes ${ }^{80}$ (see Fig. 5.13).

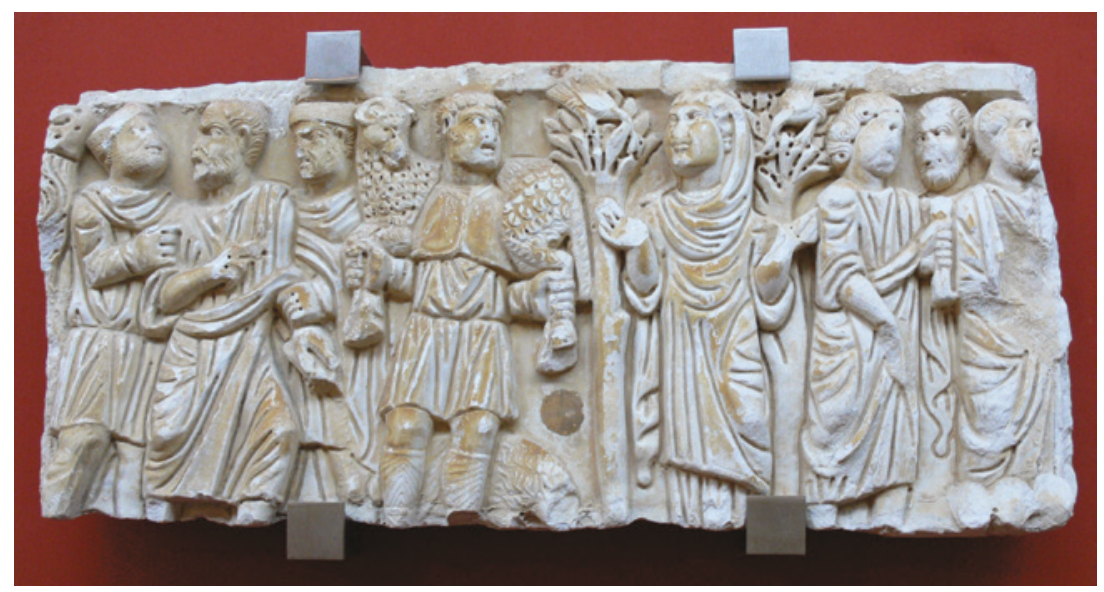

Fig. 5.13 Paired on sarcophagus. Flanked by gospel scenes. Sarcophagus fragment, second quarter of the fourth century. Courtesy Author and Musée Départemental Arles antique. Sarcophagus of the Good Shepherd, second quarter of the fourth century, Carrera marble, ferous alloy. Inv. No. FAN.92.00.2521 
Another pairing is on what may be the oldest known Eucharistic utensil. This lead vessel stamped with early Christian symbols that was found in Tunisia and is dated between 350 and the early 400s. ${ }^{81}$ Tertullian, who lived in Tunisia, wrote about Christians who painted the shepherd on their cups and chalices to represent Jesus. This artist seems to have followed that iconographic tradition. ${ }^{82}$ This artist paired the shepherd and the arms-raised woman on opposite faces of the utensil, much as later chalices paired them. Other symbols on the vessel, such as two deer drinking from a stream with a cross above, identify it unquestionably as Christian. The vessel was inscribed, "Take the water with joy." 83 Some first-century Jewish communities, such as the Therapeutae, in their gender-parallel meal ritual in Judea, used only water, not wine. Andrew B. McGowan says early Jesus communities also had a variety of Eucharistic rituals, and by the end of the first century, at the latest, some used bread and water, not bread and wine. ${ }^{84}$ It seems likely this vessel was used by that stream of Christianity (see Fig. 5.14).

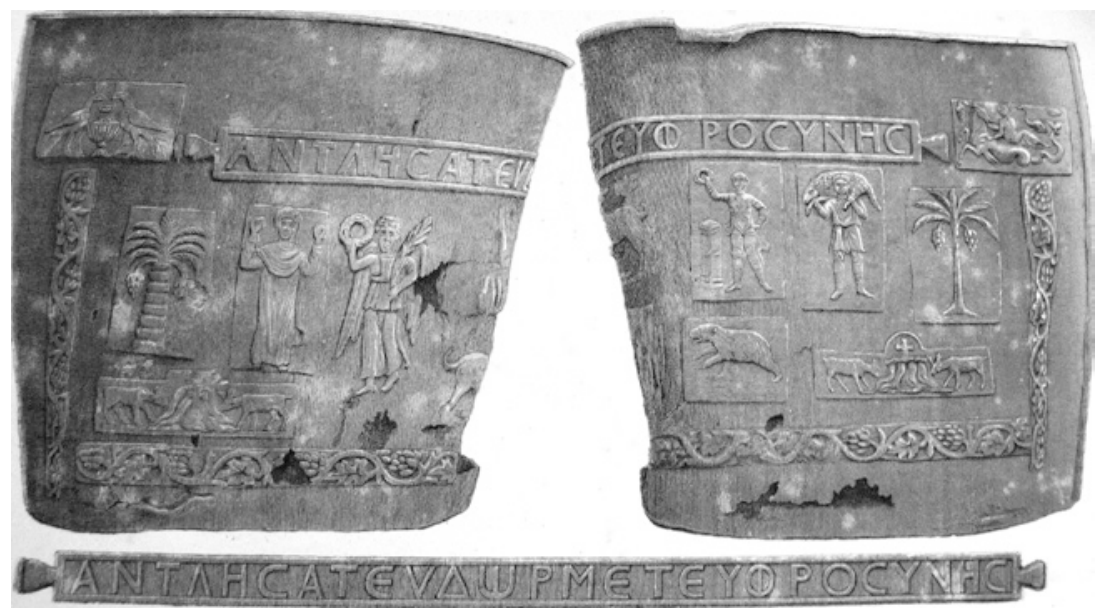

Fig. 5.14 Arms-raised woman and shepherd on a vessel: "Take the water with joy." 350 to early 400s. Tunisia. De Rossi, "Secchia di piombo" 


\section{Mother and Son Paired \\ In Third- And Fourth-Century Funereal ArT}

According to Robin Jensen, during the third and fourth centuries the arms-raised woman and shepherd "were extremely popular and appear in Christian art more than any biblical subject." 85 Could they be the mother-son dyad? The fourth-century Novalje box's identification of an armsraised woman named Mary paired with a shepherd representing Jesus in the midst of gospel scenes provides a new possibility for one of the greatest art history mysteries-who is the arms-raised woman in Christian catacomb art? More than two hundred images of this woman have been found in the Christian catacombs, but scholars have yet to agree who, or what, she represents. ${ }^{86}$

Some scholars call this arms-raised woman, who was so prevalent in catacomb art, a metaphor, an allegory of the church, a symbol of the soul, or some other symbol. ${ }^{87}$ Stine Birk says the arms-raised gesture on a woman in catacomb art is "suggestive of some of the social roles that were open to women in early Christian society. She could apparently teach, preach, or act as a spiritual leader-even for men." ${ }^{88}$ In the Vatican Museum, the arms-raised woman is almost always called a deceased woman. Nicola Denzey describes the oddity of seeing so many catacomb images of deceased women: "Where are the men and children in these family graves?" 89

Jensen suggests that the frequent juxtaposition of the arms-raised woman and the shepherd in the Christian catacombs "justifies explaining the pairing as a convention of early Christian funerary imagery. The two balanced each other. Perhaps one represented the deceased's prayers for salvation and the other the one who could fulfill those prayers." 90 Jensen's interpretation mirrors the roles of Mary and Jesus in the Dormition narrative, where Mary raised her arms and prayed, and Jesus came down and took her up with him to heaven, fulfilling her prayers. For the bereaved, this pair served as an illustration of the power of prayer, and especially, of Jesus's promise that the beloved dead would live again. Sculptors often paired the arms-raised woman and the shepherd, sometimes on plaques, ${ }^{91}$ sometimes on the opposite ends of sarcophagi, balancing each other, and sometimes, they flanked a portrait of the deceased $^{92}$ (see Figs. 5.15 and 5.16). 


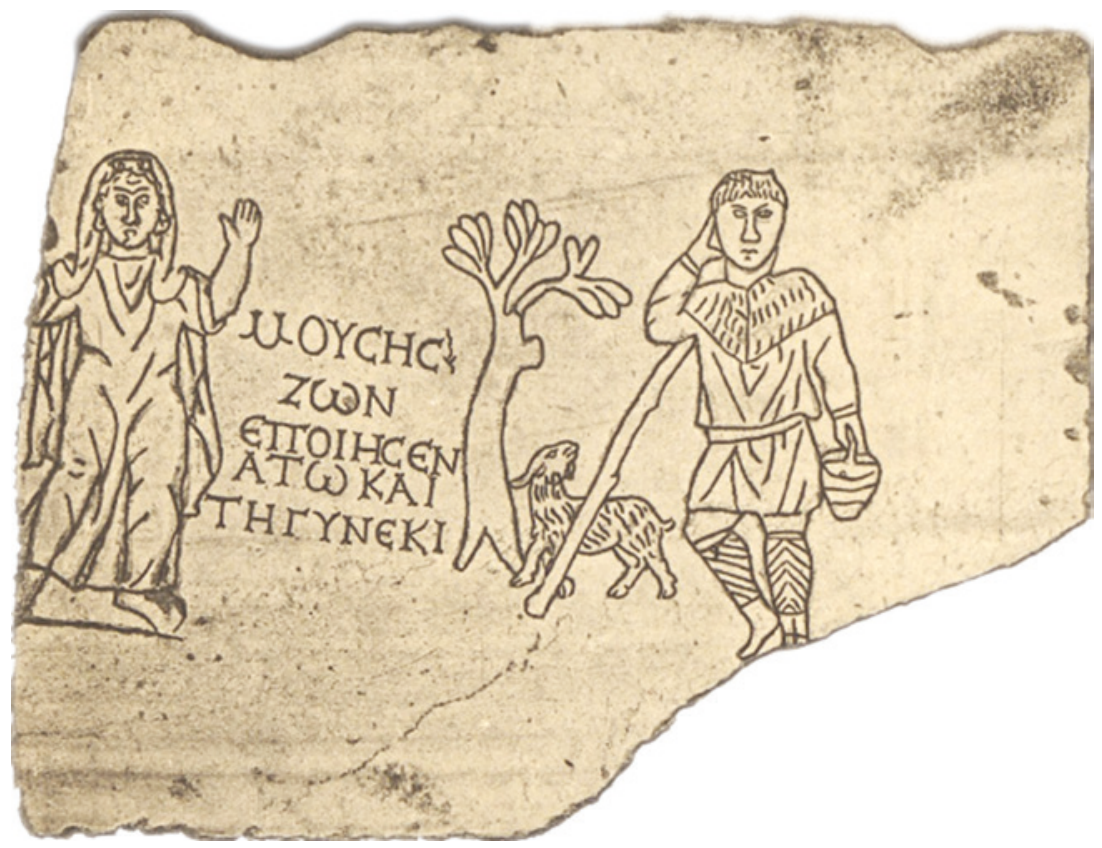

Fig. 5.15 Arms-raised woman and shepherd paired on catacomb plaque. Thirdcentury, Rome. Vatican Museum. Marucchi, Monumenti del Museo Cristiano, pl. 57

In a 2015 article in the Journal of Early Christian Studies, I proposed that an anonymous woman, or her family, may have commissioned frescos in the Cubiculum of the Velata in the Priscilla Catacomb with the intent of patterning her portrait after Mary. ${ }^{93}$ The association of Mary with women, especially when she was described arms-raised, seems likely to have been an old tradition. In any case, the Six Books originally contained multiple scenes of Mary raising her arms to bless women. For example, the "S-2" fragment says Mary "called the women of her neighborhood," invited them to go to Bethlehem with her, and then "stretched out her hands to heaven, and blessed them." "94 The medieval Arabic preserves that when women came from around the Mediterranean to Jerusalem, Mary raised her arms and blessed them. ${ }^{95}$ Yet another scene, partially preserved in both the fifth-century palimpsest and the Arabic, originally depicted Mary raising her hands and blessing the women who lived with her. ${ }^{96}$ 
126 A. KATEUSZ

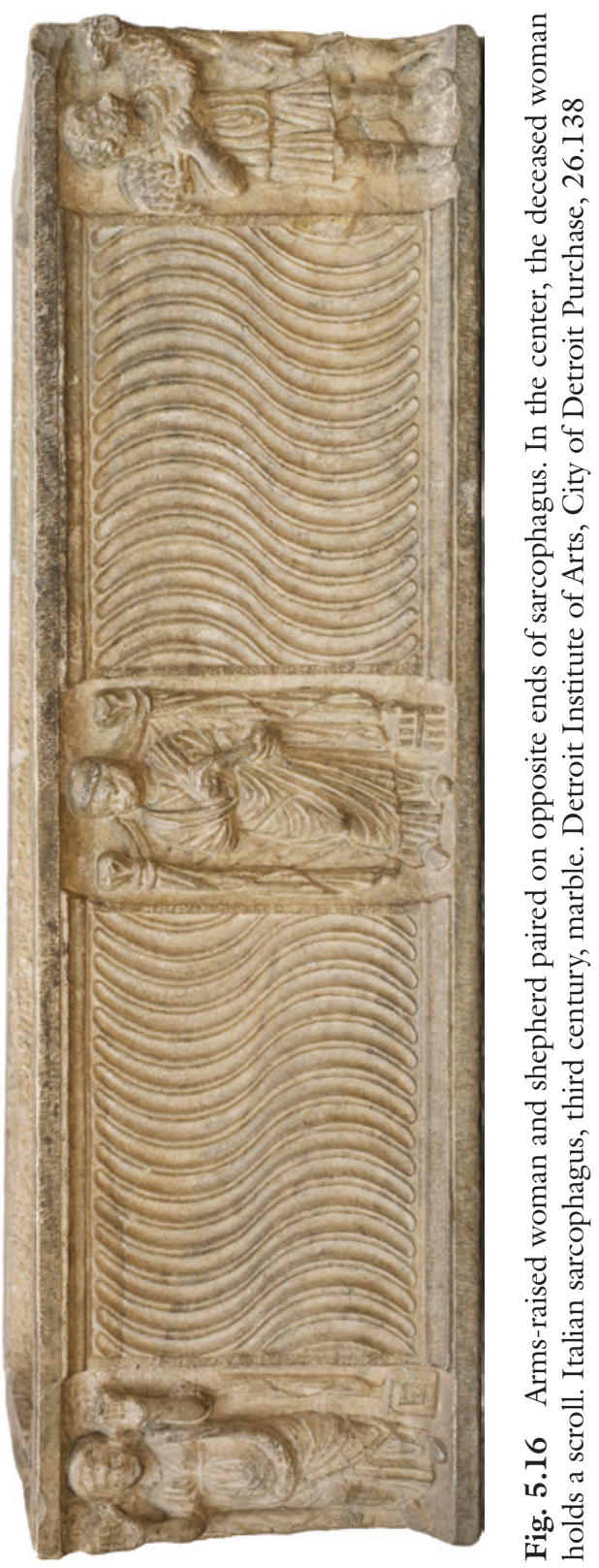


The Cubiculum of the Velata contains what appears to be the core vertical composition of the Six Books scene. The large central woman stands with her arms raised directly beneath a shepherd inside a circle. The arms-raised woman is flanked by two vignettes, each depicting a young woman with similar facial features. The right-hand vignette portrays the young woman seated on a large round-backed chair holding an infant in a composition that closely resembles the way Mary looks holding her infant in the fresco of the Adoration of the Magi, above in Fig. 5.9. The left-hand vignette portrays three people, a young woman holding what is usually identified as a book or a scroll, along with a bearded man next to her, and a young, beardless man standing behind her. Some scholars suggest that a woman holding a book wanted to be remembered as literate. ${ }^{97} \mathrm{~A}$ book could also mean that she wanted to be remembered like Mary, because the Dormition narratives associated Mary with books, as did Ambrose (340-397) and Jerome (347-420). ${ }^{98}$ The deceased woman's portrait therefore may have been patterned after Mary. If so, these three scenes signified that the deceased woman, like Mary, had been a mother, a literate woman, and a religious leader (see Fig. 5.17).

The oldest surviving example of the core vertical composition aboveground is on a wood door panel on the doors of the Santa Sabina Basilica. These are the same doors that preserved the Adoration of the Magi with Mary holding her son while elevated as the seventh step. ${ }^{99}$ When the door panel with the core vertical composition and the fresco in the Cubiculum of the Velata are compared side-by-side, the similarities between the two compositions are substantial. In both, a young man stands inside a circle. He holds up his right hand, as if in greeting. Directly beneath him stands an arms-raised woman. On the panel, she is portrayed in the less powerful-looking semi-profile Madonna advocata arms-raised pose that became so popular for Mary in Rome. In the catacombs, a peacock, the symbol of eternal life, was painted over her head, while on the church door, a circle with a cross was carved over her head. The biggest difference is that in the Cubiculum of the Velata, she is flanked by two vignettes that feature a woman, whereas on the church door a century later, she is flanked by two men-one balding and one with bangs, Paul and Peter ${ }^{100}$ (see Figs. 5.17 and 5.18).

The Santa Sabina wood door panel is adjacent to a second panel that depicts Jesus being lifted by angels into the clouds-a scene very much 
Fig. 5.17 Flanked by frescos of a woman. Ca. 300. Cubiculum of the Velata, Priscilla catacomb, Rome. Courtesy J.M. Gilbreath

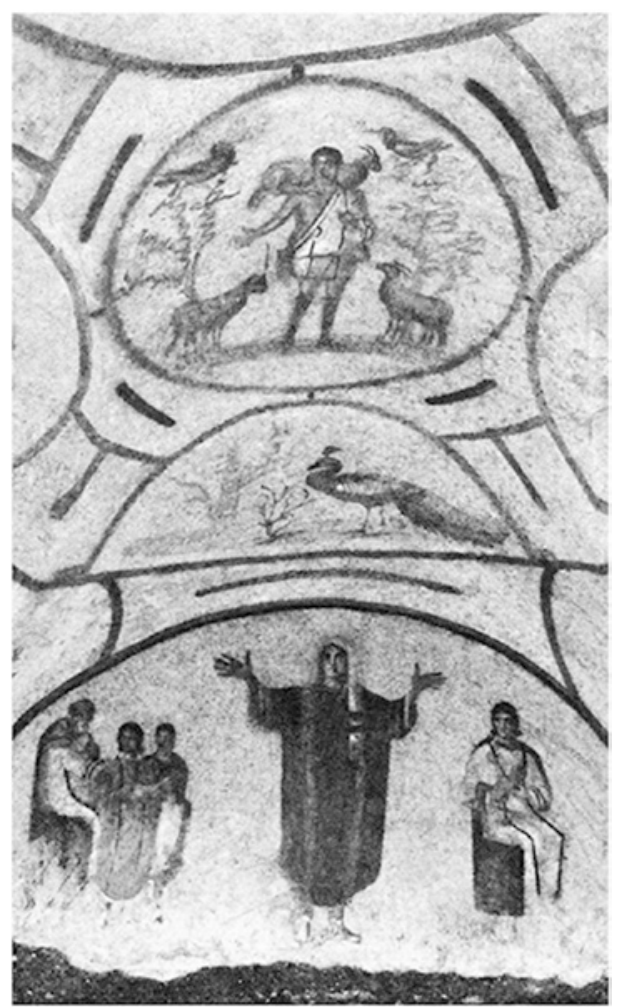

like one on a famous ivory dated 400, which likewise depicts Jesus being lifted into the clouds, but which also has a second scene below it, which depicts the two Marys at the tomb. The women at the tomb in the composition suggest that that when Jesus is seen lifted into the clouds, it represents his ascension. ${ }^{101}$ Thus, iconography depicting the heavenly ascents of both mother and son are seen, side-by-side, on the Santa Sabina doors-just as mother and son were paired in so much other art.

The long cultural durée of Marian religion, a continuity most clearly witnessed in art, is evoked by the images of a woman in modern cemeteries around Rome. The woman portrayed in these cemeteries is never considered the portrait of a dead woman-despite that sometimes her portrait is placed over the door of a family mausoleum or on 
Fig. 5.18 Flanked

by Peter and Paul. 420-430. Santa Sabina

Basilica door panel, Rome. Wiegand, Altchristliche, pl. 18

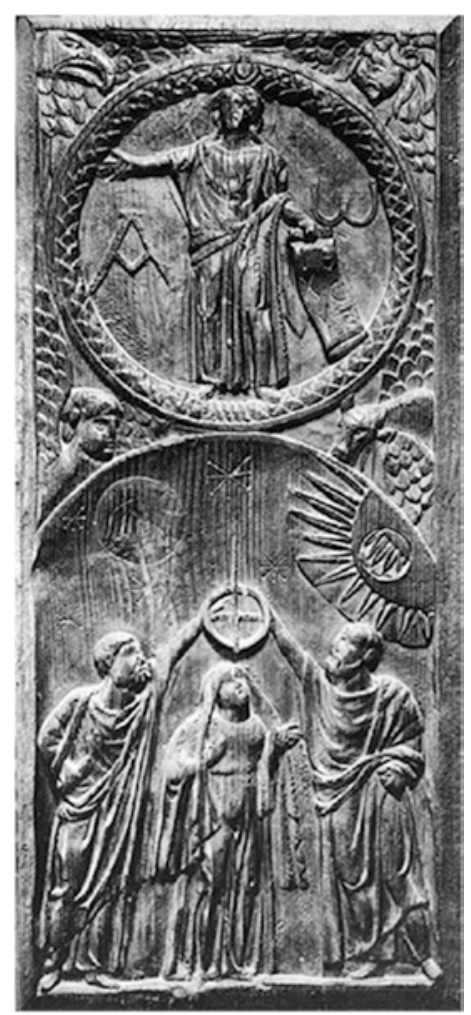

a tombstone. Sometimes she is portrayed praying while standing by herself. Sometimes she is portrayed with her son, both as an infant and as a grown man. Although, as in the catacombs, this featured woman is virtually never named, the families who buy the tombstones and tend the memory of their dead seem to know who she is-Mary pray for us. ${ }^{102}$

Mary is the sole woman who in the fourth century was identified by name when depicted arms-raised and paired with a shepherd-on the Novalje reliquary box. The pairing of mother and son, however, is seen in even older catacomb art, from the Adoration of the Magi to their pairing on sarcophagi. This pairing continued for centuries in art, including perhaps most prominently, on Eucharistic utensils. The Six Books explains why mother and son were vertically paired; this iconography 
represented the scene of her praying to her son in heaven, a scene associated with her own death and ascension, or Assumption, to heaven. But why were mother and son horizontally paired? Did their side-by-side pairing perhaps represent a scene from a long lost, or nearly lost, gospel?

Open Access This chapter is licensed under the terms of the Creative Commons Attribution-NonCommercial-NoDerivatives 4.0 International License (http:// creativecommons.org/licenses/by-nc-nd/4.0/), which permits any noncommercial use, sharing, distribution and reproduction in any medium or format, as long as you give appropriate credit to the original author(s) and the source, provide a link to the Creative Commons licence and indicate if you modified the licensed material. You do not have permission under this licence to share adapted material derived from this chapter or parts of it.

The images or other third party material in this chapter are included in the chapter's Creative Commons licence, unless indicated otherwise in a credit line to the material. If material is not included in the chapter's Creative Commons licence and your intended use is not permitted by statutory regulation or exceeds the permitted use, you will need to obtain permission directly from the copyright holder.

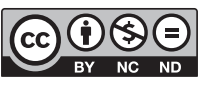

